Journal of the Egyptian Society of Parasitology, Vol.43, No.1, April 2013

J. Egypt. Soc. Parasitol., 43(1), 2013: 115 - 124

\title{
POTENCY AND PERSISTENCE OF THE BACTERIAL MOSQUITOCIDE BACILLUS SPHAERICUS AGAINST CULICINE MOSQUITOES UNDER FIELD CONDITIONS
}

\section{By}

\author{
HANY A. KAMAL ${ }^{1}$ AND EMAD I. M. KHATER ${ }^{2,3}$
}

Research and Training Centre on Vectors of Diseases, Ain Shams University $^{1}$ (hanykamal1963@yahoo.com), Department of Plant Protection², College of Food and Agricultural Sciences, King Saud University, Riyadh 11451, POB 2460, Saudi Arabia and Department of Entomology ${ }^{3}$, Faculty of Science, Ain Shams University Cairo 11566, Egypt.

\section{Abstract}

The biopesticide Bacillus sphaericus represents one of the important tools used in the control of mosquito larvae after chemical insecticides. The present study was conducted to investigate the efficacy $B$. sphaericus 2362 (VectoLex) in two different technical powders, ABG-6232 and ABG-6491 against larvae of two mosquitoes, Culex pipiens and Aedes caspius in El-Arish city, North Sinai, Egypt.

The mosquito larvae were collected from polluted and fresh water (Cx.pipiens) and saline water (Ae. caspius). The physicochemical characteristics of larval breeding water sites were measured as salinity, conductivity, $\mathrm{pH}$ values and temperature.

Susceptibility bioassays showed that $C x$. pipiens larvae from polluted water sites have high susceptibility to $B$. sphaericus 2362 formulation ABG-6232 $\left(\mathrm{LC}_{50} 0.15\right.$ $0.33 \mathrm{ppm}, \mathrm{LC}_{90}$ : $\left.0.73-9.68 \mathrm{ppm}\right)$. In case of ABG-6491 formulation, the values were $\mathrm{LC}_{50}: 0.15-0.33 \mathrm{ppm}$ and $\mathrm{LC}_{90}: 1.73-9.83 \mathrm{ppm}$. Cx. pipiens larvae collected from fresh water habitat in El-Qusiema, outside El-Arish city, susceptibility to $B$. sphaericus $2362 \mathrm{ABG}-6232$ had $\mathrm{LC}_{50}$ values ranging between 0.12 and $0.28 \mathrm{ppm}$, while $\mathrm{LC}_{90}$ ranged between 1.59 and $4.13 \mathrm{ppm}$. In case of ABG-6491, the $\mathrm{LC}_{50}$ values ranged between 0.13 and $0.28 \mathrm{ppm}$, while $\mathrm{LC}_{90}$ values ranged between 1.46 and $8.93 \mathrm{ppm}$.

For Ae. caspius larvae from saline water and treated with B. sphaericus 2362 ABG-6232, $\mathrm{LC}_{50}$ values ranged between $0.31 \& 1.36 \mathrm{ppm}$, while $\mathrm{LC}_{90}$ ranged between $1.92 \& 9.75 \mathrm{ppm}$. In case of ABG- 6491, the $\mathrm{LC}_{50}$ values ranged between $0.34 \& 0.59 \mathrm{ppm}$, while $\mathrm{LC}_{90}$ values ranged between 1.79 and $11.56 \mathrm{ppm}$.

Keywords: Egypt, Culicine mosquitoes, Biopesticides, Field efficacy,

\section{Introduction}

Anti-mosquito bio-pesticides based on the pathogenic bacterial $B$. thuringiensis var. israelensis (Bti) and B. spha- ericus $(B s)$ are important means of the mosquito vector control, especially in an integrated vector management (IVM) programme (Dritz et al, 2011). 
Many bacterial strains and commercial formulations that have proven successful against various vector species (Medieros et al, 2005, Melo et al, 2009). Despite their relative efficacy, there was a number of disadvantages that render these bio-pesticides less effective, labour-intensive and expensive. These include low persistence and degradation due to exposure to sunlight UV. Many laboratory or simulated field or field trials improved the efficacy of the present formulations or produce new ones (Morsy and Mazyad, 2000; Lingenfelser et al, 2010). Many studies evaluated Bti or $B s$ formulation separately or in a mixture of both against many mosquito species of genera Aedes, Anopheles, Culex and Ochlerotatus (Brown et al, 2004, Majambere et al, 2007, Geraldo-Calderon et al, 2008, Melo et al, 2009, Singh and Prakash, 2009). Toxins and vegetative proteins of these bacteria were tested (Wirth et al, 2007, Jones et al, 2007). The publication of the complete genome of B. sphaericus C3-41 (Hu et al, 2008), will help improve the efficacy of the identified proteins or toxins or the identification of novel candidates with strong mosquitocidal activities.

This study aimed to assess the efficacy of two technical powders of $B$. sphaericus 2362, ABG-6232 and ABG6491 against larvae of two mosquitoes, Cx. pipiens (polluted and fresh water) and Ae. caspius (saline water) from North Sinai, North-East of Egypt.

\section{Materials and Methods}

B. sphaericus preparations: Two granulated powder preparations of $B$. sphaericus strain 2362 (ABG-6232 \&ABG-6491) from Abbott Laboratories (North Chicago, IL, U.S.A.) were used in laboratory bioassays and field evaluation. The preparations were preverved at a temperature of $5^{\circ} \mathrm{C}$. A stock suspension of $B$. sphaericus was prepared by suspending $1 \mathrm{gm}$ of the granular formulation into $100 \mathrm{ml}$ distilled water. Serial dilutions of the stock suspension done in tap water to give five to six concentrations in the range of 0.1 to $10.0 \mathrm{ppm}$ and used in each bioassay. All suspensions were prepared fresh for experimental purposes.

The laboratory susceptibility bioassay tests carried out to determine the sub-lethal concentrations of the two bacterial formulations against the two mosquito species, Cx. pipiens and Ae. caspius as described (Rodcharoen and Mulla, 1995). Twenty young fourth instar larvae were placed in waxed paper cup containing $100 \mathrm{ml}$ distilled water and treated with different concentrations from 0.001 to $0.75 \mathrm{ppm}$ of bacterial suspensions were tested in each bioassay to yield $10-95 \%$ mortality. Larvae were provided fish food (tetra$\min$ ) the 48-hr observation period. Larval mortality was assessed 48 -hr posttreatment and moribund larvae were also considered dead. All the bioassays were replicated three times.

Evaluation of the efficacy and persistence of B. sphaericus 2362 under field conditions: B. sphaericus 2362 technical formulation ABG-6232 applied for efficacy and persistence field trials. Because environmental factors such as ultraviolet light would degrade the larvicide, approximately $10 \mathrm{X}$ observed 
laboratory $\mathrm{LC}_{50}$ for each breeding site used in field experiments. The required amounts of the primary powder suspended in tap water. The aqueous suspension applied with a pressurized hand sprayer (size one liter) at the rate of $0.5-2 \mathrm{gm} / \mathrm{m}^{2}$, around the periphery and center of the target larval water habitat.

Field bacterial treatment was tested in El-Arish City, North Sinai Governorate. ABG-6232 preparations were applied to three types of larval breeding sites: polluted water, saline water and fresh water. Samples taken from the periphery and center of each studied larval site were used to estimate larval density prior treatment.

The larval densities of each site at first, second, seventh and fourteenth day post-bacterial treatment recorded. Reduction percent in larval densities post- versus pre-treatment counts were calculated.

\section{Results}

Laboratory screening of the susceptibility of two mosquito species showed that the two $C x$. pipiens populations from polluted and fresh water have comparable susceptibility, and both are more susceptible than the saline water Ae. caspius to the two bacterial formulations used based on the $\mathrm{LC}_{50}$ values (ABG-6232 and ABG-6491) and the $\mathrm{LC}_{90}$ values (ABG-6491). Regarding $\mathrm{LC}_{90}$ values to the formulation ABG6232 , the fresh water $C x$. pipiens population from more susceptible than that from polluted water $(\sim 1.8$ fold) and the saline water Ae. caspius ( 2 fold) (Tab. 2).
Efficacy and persistence of $B$. sphaericus 2362 (ABG-6232) under field conditions: For $C x$. pipiens in the polluted water-breeding site, the recorded mean number of larvae pre-treatment was 9.25larvae/dip. Bacterial treatment caused a reduction of $78.4 \%$ in larval number after 24 hrs. Complete reduction of larvae occurred after $48 \mathrm{hrs}$ and remained so to the end of the experiment. This means that the residual activity of this formulation in polluted water habitat continued for 14 days (Tab. 3, Fig. 1).

For the fresh water $C x$. pipiens, the mean number of pre-treatment larvae was 9larvae/dip. The reduction in larval number is $69.4 \%$ at $24 \mathrm{hrs}$ posttreatment, which increased to $80.6 \%$ after $48 \mathrm{hrs}$. The complete reduction of mosquito larvae occurred on the $7^{\text {th }}$ day post-treatment (Tab. 3). However, on the $14^{\text {th }}$ day, the number of larvae started to increase, which indicates a decrease in the residual activity of the bacterial formulation, by $25 \%$ of that at day 7 (Tab. 3; Fig. 1).

Saline water habitat: larva-breeding sites was treated with $2 \mathrm{gm} / \mathrm{m}^{2}$ of $B$. sphaericus 2362 (ABG-6232). Mean number of Ae. caspius larvae collected from saline water pre-treatment was 18.75 larvae/dip. Reduction in larvae densities was $54 \%, 73 \% \& 88 \%$ at 1,2 and 7 days post-treatment, respectively. But, at the $14^{\text {th }}$ day post-treatment, the larval densities started to increase, an indication of decrease in residual activity of this formulation in saline by $12 \%$ of that at $7^{\text {th }}$ day (Tab. 3, Fig. 1). These results showed that the tested mosquito species are highly susceptible to the 
two technical formulations of the $B$. sphaericus 2362 used. Cx. pipiens (from polluted and fresh water habitats) was more susceptible than Ae. caspius (saline water habitat) based on laboratory and field assays. The polluted water habitat was the most efficient in retaining the efficacy of the applied bacterial biopesticide (ABG-6232), followed by fresh and saline water habitats. In all habitats, the biopesticide remained highly effective for 14 days. Many factors contribute to these variations in biopesticide efficacy: the mosquito species, physicochemical properties of water habitats and the biopesticide formulations.

Table 1: Physicochemical characteristics of the studied mosquito larval collection water sites in Al-Arish City.

\begin{tabular}{|c|c|c|c|c|c|c|}
\hline $\begin{array}{c}\text { Water } \\
\text { site }\end{array}$ & $\begin{array}{c}\text { Mosquito } \\
\text { spp. }\end{array}$ & $\begin{array}{c}\text { Salinity } \\
(\mathrm{gm} \mathrm{CL} / \mathrm{L})\end{array}$ & $\begin{array}{c}\text { Conductivity } \\
(\mu \mathrm{mohs} / \mathrm{cm})\end{array}$ & $\mathrm{pH}$ & $\begin{array}{c}\text { Temp. } \\
\left({ }^{\circ} \mathrm{C}\right)\end{array}$ & $\begin{array}{c}\text { Areas in Al-Arish } \\
\text { district }\end{array}$ \\
\hline Polluted & Cx. pipiens & $0.06-0.23$ & $402-579$ & $6.8-8.8$ & $16-38$ & Dahiat El-Salam \\
\hline Fresh & Cx. pipiens & $0.05-0.23$ & $150-254$ & $6.9-9.0$ & $16-37$ & El-Qusiema, \\
\hline Saline & Ae. caspius & $1.8-2.5$ & $1177-1993$ & $6.5-10.5$ & $14-38$ & El-Masaeed \\
\hline
\end{tabular}

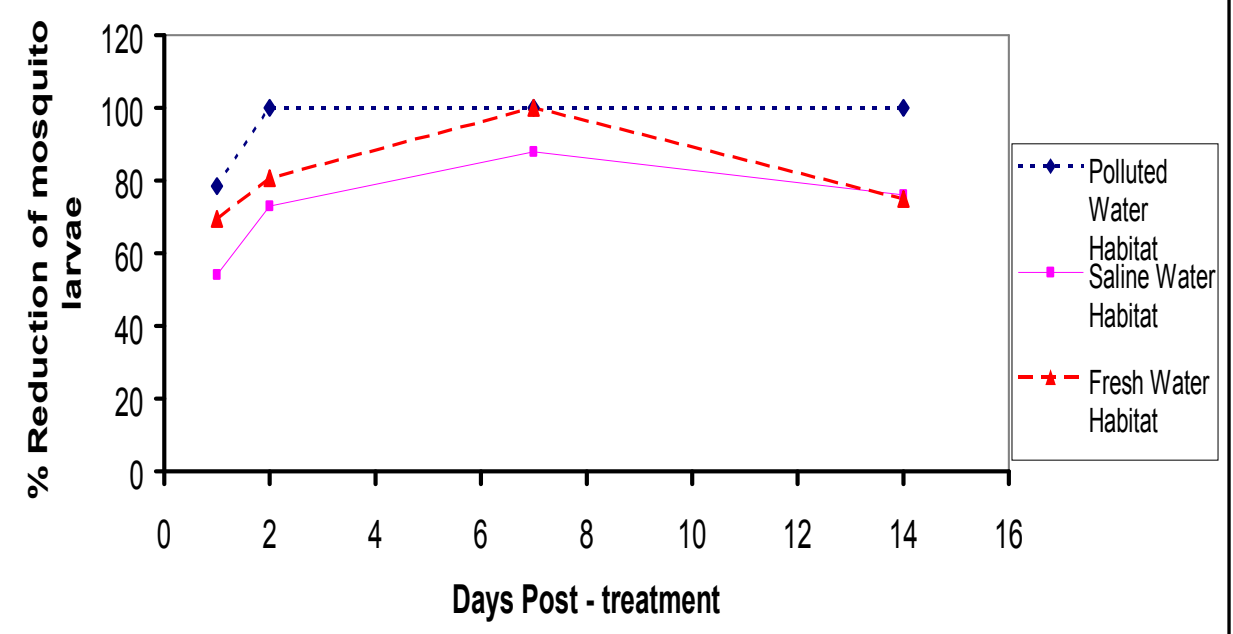

Fig. 1: Efficacy of B. sphaericus 2362 (ABG-6232) against Cx. pipiens and Ae. caspius larvae in three different breeding habitats. 
Table 2: Susceptibility of larval populations to B. sphaericus 2362 commercial formulations, ABG-6232 \&ABG-6491 from water sites in Al-Arish City.

\begin{tabular}{|c|c|c|c|c|c|}
\hline \multirow{2}{*}{$\begin{array}{c}\text { Water } \\
\text { Site }\end{array}$} & & \multicolumn{3}{|c|}{ ABG-6232 } \\
\cline { 2 - 6 } & Mosquito* & \multicolumn{2}{|c|}{ LC $_{50}(\mathrm{ppm})$} & \multicolumn{2}{c|}{ ABG-6491 } \\
\hline Polluted & Cx. pipiens & $0.24(0.15-0.33)$ & LC $90(\mathrm{ppm})$ & $\mathrm{LC}_{50}(\mathrm{ppm})$ & $\mathrm{LC}_{90}(\mathrm{ppm})$ \\
\hline Fresh & Cx. pipiens & $0.20(0.12-0.28)$ & $5.21(0.73-9.68)$ & $0.24(0.15-0.33)$ & $5.78(1.73-9.83)$ \\
\hline Saline & Ae. caspius & $0.84(0.31-1.36)$ & $2.86(1.59-4.13)$ & $0.25(0.13-0.28)$ & $5.2(1.46-8.93)$ \\
\hline
\end{tabular}

Table 3: Efficacy of B. sphaericus 2362 (ABG-6232) against $C x$. pipiens and Ae. caspius larvae in three different natural breeding habitats.

\begin{tabular}{|c|c|c|c|c|c|c|c|}
\hline \multirow{2}{*}{$\begin{array}{c}\text { Breeding } \\
\text { Site }\end{array}$} & \multirow{2}{*}{ Mosquito } & $\begin{array}{c}\text { Bacterial dosage } \\
\left(\mathrm{gm} / \mathrm{m}^{2}\right)\end{array}$ & $\begin{array}{c}\text { Pre-treatment } \\
\text { (day) }\end{array}$ & \multicolumn{4}{|c|}{$\begin{array}{c}\text { Post-treatment } \\
\text { (Reduction \%) }\end{array}$} \\
\hline & & & $\mathrm{D} 0$ & $\mathrm{D} 1$ & $\mathrm{D} 2$ & $\mathrm{D} 7$ & $\mathrm{D} 14$ \\
\hline Polluted & Cx. pipiens & 1.5 & 9.25 & $\begin{array}{c}2 \\
(78.4)\end{array}$ & $\begin{array}{c}0 \\
(100)\end{array}$ & $\begin{array}{c}0 \\
(100)\end{array}$ & $\begin{array}{c}0 \\
(100)\end{array}$ \\
\hline Fresh & Cx. pipiens & 1 & 9 & $\begin{array}{c}2.75 \\
(69.4)\end{array}$ & $\begin{array}{c}1.75 \\
(80.6)\end{array}$ & $\begin{array}{c}0 \\
(100)\end{array}$ & $\begin{array}{c}2.25 \\
(75)\end{array}$ \\
\hline Saline & Ae. caspius & 2 & 18.75 & $\begin{array}{c}8.5 \\
(54.7)\end{array}$ & $\begin{array}{c}5 \\
(73.3)\end{array}$ & $\begin{array}{c}2.25 \\
(88)\end{array}$ & $\begin{array}{c}4.5 \\
(76)\end{array}$ \\
\hline
\end{tabular}

\section{Discussion}

In the present study, B. sphaericus 2362 (ABG-6232) provided extremely effective control of mosquito larvae in all breeding sites, especially polluted and fresh breeding ones, against $C x$. pipiens larvae and to a lesser degree against Ae. caspius larvae in saline breeding habitat. Field application of $B$. sphaericus resulted in significant reduction of $C x$. pipiens populations (Wirth et al, 2001) and in An. species (Wirth et al, 2000). The appropriate formulations of $B$. sphaericus showed significant residual activity against $C x$. pipiens in the highly polluted breeding sites. Extended activity of $B$. sphaericus was explained by Lacey and Udeen (1986) to be due to recycling of spores in larval cadavers or to persistence of sufficient quantities of toxin in the habitat. Also, the extended control can be explained by the fact that larvae ingest spores settled into bottom water and mud (Matanmi et al, 1990). On the other hand, it has been shown that $B$. sphaericus provides a higher level of control in fresh than polluted water (Mulla et al, 1988). They concluded that in general, higher rates than that of the fresh water rates are required to achieve satisfactory control of larvae in polluted water breeding sites.

B. sphaericus has the potential to persist and recycle under field conditions, for up to 3 months (Jones et al, 1990). In previous studies, a powder preparation of strain 2362 proved to be the most active preparation tested, yielding excellent control of stagnant and flood water mosquitoes such as $C x$. tarsalis, Cx. pipiens, Ae. nigromaculis and Ae. melanimon (Chabanenko et al, 1992). A number of factors can influence the level and duration of larvicidal effect of $B$. sphaericus in mosquito habitats. These include water quality and depth, solar radiation, target spe- 
cies and larval density (Yousten et al, 1984). Moreover, non-target organisms can play an important role in recycling $B$. sphaericus, since the bacterium was able to germinate in the larval guts of Chironomus species and other filterfeeding arthropods such as Daphnia (Karch et al, 1990).

In the present study, high efficacy of B. sphaericus in the polluted breeding site was related to the presence of high densities of aquatic invertebrates and arthropods.

The present results also revealed that $B$. sphaericus provided effective extended mosquito control in all types of breeding sites especially the polluted habitat. This agreed with that of Karch et al. (1990) and Mulla et al. (2001). Decline in immature populations followed by a substantial decline in adult mosquitoes (Mulla et al, 2001). The granule formulation proved to be highly effective against the polluted stagnant water mosquito (Lacey and Lacey, 1990). The present study agreed with Mulla (1991) who reported that the binary crystalline toxins produced by B. sphaericus strain 2362 have high activity against larvae of Culex mosquitoes, and with Mulla et al. (1997) who reported that B. sphaericus 2362 granular formulations gave high mortality of $C x$. pipiens field conditions especially in highly polluted water. Besides, Lacey et al. (1988) reported that $B$. sphaericus activity was positively related to the amount of food available to mosquito larvae in artificial container. The duration of control is also dependent on the product, the transient nature of some sites, and the target mosquito larvae (Skovmand and Sanogo, 1999).

Spores of B. sphaericus persisted for months in larval habitats and cadavers (Berry et al, 1987). Spores grow in larval cadavers, which provide protection for the bacteria from the deleterious effect of the sunlight (Des Rochers and Garcia, 1984). B. sphaericus recycled in dead larvae both in the laboratory and in the field, producing an increase of 100 to 1000 fold in spore numbers (Davidson et al, 1984). Nicolas et al. (1987b) stated that the final amount of spores recycled in dead larvae as affected by organic matter.

In the present study, B. sphaericus 2362 (ABG-6232) proved to be persistent and more active against $C x$. pipiens larvae in the deep, shaded, polluted mosquito breeding site than in the fresh breeding one which was relatively less in depth and exposed to sunlight. This observation agrees with that of Mulligan et al. (1980) who reported several reasons for extended suppression of mosquito breeding sites, namely, water movement, depth, rains, and exposure to sunlight known to reduce $B$. sphaericus activity under field conditions.

The present results revealed less efficacy and persistence of $B$. sphaericus against Ae. caspius larvae in the saline breeding site. This may be because the water in this breeding site was shallow, completely exposed to sunlight and contained solid materials. This agreed with Nicolas et al. (1987a). But, Davidson (1985) recorded many advantages of $B$. sphaericus such as its 
persistence and ability of recycling, the author stated that its main disadvantage was its relatively narrow mosquito host range since it was virtually inactive against $A e$. aegypti and certain other Aedes species.

Additional advantage of this microbial agent is being environmentally safe and without adverse effects on dominant macro-invertebrate fauna, especially predacious insects (Mulla et al, 1984). The microbial agent B. sphaericus proved to be an excellent alternative to chemical larvicides for mosquitoes control, especially $C x$. pipiens, the main vector of Bancroftian filariasis in Egypt (Hougard et al, 1993). This bacterial agent is environmentally safe due to its host specificity, required in very low dosage, easy to prepare commercially in a large-scale and its less costly (Bhattacharya, 1998).

Undoubtedly, mosquitoes-borne diseases are threat worldwide (Mikhail et al, 2009). In Egypt, the re-emerging of Aedes aegypti in Aswan Governorate (Essam et al, 2006) and in Toshka Project (Shoukry and Morsy, 2011; Shoukry et al, 2012), which is the main vector of Yellow fever (CDC, 2010a), Dengue hemorrhagic fever (El-Bahnasawy et $a l, 2011)$ and Chikungunya viruses (CDC, 2010 b).

Moreover, the recent demonstration of the Yellow fever in the Northern Sudan is another risk health problem (Markoff, 2013).

On the other hand, the threating of the Rift Valley fever (El-Bahnasawy et $a l, 2013$ ) and West Nile fever (Abbassy et al, 1993; Darwish et al, 1996; Kro- man et al, 2012) to Egypt are all risk factors paving the way to an urgent need for mosquito control by a feasible ecological friend agent.

\section{Conclusion}

The study carried out revealed various levels of efficacies of the tested bacterial agents due to experimental conditions, material used and most important the specific susceptibility and ecology of the tested mosquito.

To obtain comprehensive evaluation of their efficacies, all available formulations of these bio-pesticides, should be used on a range of mosquito vectors in different geographic regions in all possible larval habitats.

No doubt, the public health, the veterinary and the agricultural authorities must take into consideration that the control of the mosquito-vectors of infectious diseases with a safe and environmental agent like bacillus is the first feasible control measure to prevent transmission of such infectious diseases to man. The prevention was and is always better than treatment in a country like Egypt which lies at the cross roads of many countries.

\section{References}

Abbassy, MM, Osman, M, Marzouk, AS, 1993: West Nile virus (Flaviviridae: Flavivirus) in experimentally infected Argas ticks (Acari: Argasidae). Am. J. Trop. Med. Hyg. 48, 5:726-37.

Berry, WJ, Novak, MG, Khounlo, S, Rowley, WA, Melchior, GL, 1987: Efficacy of B. sphaericus and B. thuringiensis var. israelensis for control of $C x$. pipiens and flood water $A e$. larvae 
in Iowa. J. Am. Mosq. Cont. Assoc. 3, 4:579-82.

Bhattacharya, PR, 1998: Microbial control of mosquitoes with special emphasis on bacterial control. Indian J. Malariol. 35, 4:206-26.

CDC, 2010a: Fact Sheet/Yellow Fever.http://www.cdc.gov/ncidod/dvbid/ye llowfever/yf_factsheet.html:

CDC, 2010b: Chikungunya Distribution and Global Map: For information on current outbreaks, consult CDC's Travelers Health (http://www.cdc. gov/ travel/def-fault.aspx).

Chabanenko, AA, Bogdanova, EN, Ermishev, IV, Dremova, VP, 1992: The efficacy of a combined preparation based on Bacillus sphaericus and B. thuringiensis $\mathrm{H}-14$ against the larvae of blood-sucking mosquitoes. Med. Parasitol (Mosk), 30, 1:23-5.

Darwish, M, el-Khashaab, TH, Mostafa, A, Hamid, TA, Shope, R, 1996: A comparative study of serological techniques for detection of West Nile virus antibodies. J. Egypt. Pub. Hlth Assoc. 71, 3/4:201-11.

Davidson, EW, 1985: Bacillus sphaericus as a microbial control agent for mosquito larvae. J. Mosq. Cont. Methodol. 2:213-226.

Davidson, EW, Urbina, M, Payne, J, Mulla MS, Darwazeh, H, et al, 1984: Fate of Bacillus sphaericus 1593 and 2362 spores used as larvicides in the acquatic environment. App. Environ. Microbiol. 47, 1:125-9.

Des Rochers, B, Garcia, R, 1984: Evidence for persistence and recycling of B. sphaericus. Mosq. News, 44, 2:160-
2.

Dritz, DA, Lawler, S, Evkhanian, C, Graham, P, Baracosa, V, et al, 2011: Control of mosquito larvae in seasonal wet-lands on a wildlife refuge by using VectoMax CG. J. Am. Mosq. Cont. Assoc. 27, 4:398-403.

El-Bahnasawy, ММ, Khalil, ННМ, Morsy, AT, Morsy TA, 2011: Threat of dengue fever, and dengue hemorrhagic fever to Egypt from travelers. J. Egypt. Soc. Parasitol. 41, 2:289-306.

El-Bahnasawy, MM, Megahed, LA, Saleh, HAA, Morsy, TA, 2013: The Rift valley fever: Could re-emerge in Egypt again? J. Egypt. Soc. Parasitol. 43, 1:41-56.

Essam, Abdel SS, Deon, Vahid C, Bruce, B, Mohamed, Wagdy, FY, Abdel Wahab, HA, 2006: Efficacy of botanical extracts from Callitris glaucophylla, against Aedes aegypti and Culex annulirostris mosquitoes. Trop. Biomed. 23, 2:180-5.

Hougard, JM, Mbentengam, R, Lochouarn, L, Escaffer, H, Darriet, F, et al, 1993: Campaign against $C x$. quinquefasciatus using B. sphaericus; results of a pilot project in a large urban area of equatorial Africa. Bull. WHO, 71, 3/4:367-75.

Jones, JW, Weathersbee, AA, Efrid, P, Meisch, MV, 1990: Evaluation of Bacillus sphaericus 2362 against $C x$. quinquefasciatus in septic ditches. J. Am. Mosq. Cont. Assoc. 6, 3:496-9.

Karch, S, Monteny, N, Jullien, JL, Sinegre, G, Coz, J, 1990: Control of Culex pipiens by Bacillus sphaericus and role of non-target arthropods in its 
recycling. J. Am. Mosq. Cont. Assoc. 6, 1:117-54.

Kropman, E, Bakke, LJ, de Sonnaville, JJ, Koopmans, MP, Raaphorst, J, et al, 2012: West Nile virus poliomyelitis after a holiday in Egypt. Ned. Tijdschr. Geneeskd. 155, 35: A4333.

Lacey, LA, Lacey, CM, 1990: Medical importance of rice land mosquitoes and their alternatives to chemical insecticides. J. Am. Mosq. Cont. Assoc. 2:193.

Lacey, LA, Undeen, AH, 1986: Microbial control of black flies and mosquitoes. Ann. Rev. Entomol. 31:26596.

Lacey, LA, Lacey, CM, Peacock, B, Thierg, I, 1988: Mosquito host-range and field activity of $B$. sphaericus isolate 2297 (serotype 25). J. Am. Mosq. Cont. Assoc. 3, 1:51-6.

Lingenfelser, A, Rydzanicz, K, Kaiser, A, Becker, N, 2010: Mosquito fauna and perspectives for integrated control of urban vector-mosquito populations in Southern Benin (West Africa). Ann. Agric. Environ. Med. 17, 1: 49-57.

Markoff, L, 2013: Yellow fever; outbreak in Sudan, NEJM, February 6, Doi: 10.1056/NEJMp1300772.

Matanmi, BA, Federici, BA, Mulla, MS, 1990: Fate and persistence of $\mathrm{Ba}$ cillus sphaericus used as a mosquito larvicide in dairy wastewater lagoons. J. Am. Mosq. Cont. Assoc. 6, 3:384-9.

Mikhail, MW, Al-Bursheed, KhM, AbdEl-Halim, AS, Morsy, TA, 2009: Studies on mosquito borne diseases in
Egypt and Qatar. J. Egypt. Soc. Parasitol. 39, 3:745-56.

Morsy, TA, Mazyad, SA, 2000: Bacillus thuringiensis var. israelensis (B.t. sero-type H-14) against Lucilia sericata third stage larvae. J. Egypt. Soc. Parasitol. 30, 2:573-80.

Mulla, MS, 1991: Biological control of mosquitoes with entomopathogenic bacteria. J. Entomol. Spec. Publ. 6:93104.

Mulla, MS, Darwazeh, HA, Davidson, EW, Dulmage, HT, 1984: Larvicidal activity and field efficacy of $B$. sphaericus strains against mosquito larvae and their safety to non-target organisms. Mosq. News 44:336-42.

Mulla, MS, Darwazeh, HA, Tietze, NS, 1988: Efficacy of Bacillus sphaericus 2362 formulations against floodwater mosquitoes. J. Am. Mosq. Cont. Assoc. 4, 2:172-4.

Mulla, MS, Rodcharoen, J, Ngamsuk, W, Tawatsin, A, Pan-Urai, P, et al, 1997: Field trials with $B$. sphaericus formulations against polluted water mosquitoes in a Suburban area, Bangkok, Thailand. J. Am. Mosq. Cont. Assoc. 13, 14:297-304.

Mulla, MS, Thavara, U, Tawatsin, A, Ngamsuk, W, Chompoosri, J, et al, 2001: Mosquito larval control with Bacillus sphaericus: reduction in adult population in low-income communities in North Aburi Province, Thailand. J. Vector Ecol. 26, 2: 221-31.

Mulligan, FS, Schaefer, CH, Wilder, WH, 1980: Efficacy and persistence of Bacillus sphaericus against mosquitoes 
under the laboratory and field conditions. J. Econ. Entomol. 73:684-8.

Nicolas, L, Darriet, F, Hougard, JM, 1987a: Efficacy B. sphaericus 2362 against larvae of An. gambiae under laboratory and field conditions in West Africa. Med. Vet. Entomol. 1:157-62.

Nicolas, L, Dossou-Yovo, J, Hougard, JM, 1987b: Persistence and recycling of B. sphaericus 2362 spores in $C x$. quinquefasciatus breeding sites in West Africa. Appl. Microbiol. Biotech. 25:341-5.

Rodcharoen, J, Mulla, MS, 1995: Comparative ingestion rates of $C x$. quinque fasciatus (Diptera: Culicidae) susceptible and resistant to $B$. sphaericus. J. Invert. Pathol. 66:242-8.

Shoukry, NM, Elwan, MA, Morsy, T A, 2012: Aedes aegypti (Linnaeus) reemerging in southern Egypt. J. Egypt. Soc. Parasitol. 42, 1:41-50.

Shoukry, NM, Morsy, TA, 2011: Arthropod borne diseases at Toshka, Upper Egypt. Wld. J. Zool, 6, 2:126-33.
Skovmand, AE, Sanogo, E, 1999: Experimental formulations of $B$. sphaericus and $B$. t. $i$. against $C x$. quinquefasciatus and An. gambiae (Diptera: Culicidae) in Burkina. J. Med. Entomol. 36, 1: 62-7.

Wirth, MC, Federici, BA, Walton, W E, 2000: Cytl. A from Bacillus thuringiensis israelensis synergizes activity of B. sphaericus against Ae. aegypti (Diptera: Culicidae). Appl. Environ. Microbiol. 66, 3:1593-7.

Wirth, MC, Ferrari, JA, Georghiou, GP, 2001: Baseline susceptibility to bacterial insecticides in populations of Cx. pipiens complex (Diptera: Culicidae) from California and from the Mediterranean Island of Cyprus. J. Econ. Entomol. 94, 4: 920-8.

Yousten, AA, Wallis, DJ, Singer, S, 1984: Effect of oxygen on growth sporulation and mosquito larval toxin formation by B. sphaericus 1593 . Curr. Microbiol. 11:175-8. 